\title{
Genetic identification method for two subspecies of the Indonesian short-finned eel, Anguilla bicolor, using an allelic discrimination technique
}

\author{
Chikaya Tanaka ${ }^{1}$, Fumiaki Shirotori', Masaki Sato ${ }^{1}$, Mina Ishikawa' ${ }^{1}$ Akira Shinoda ${ }^{2}$, Jun Aoyama ${ }^{3}$ \\ and Tatsuki Yoshinaga ${ }^{1 *}$
}

\begin{abstract}
Background: There is an increasing pressure on tropical species of the freshwater eel genus Anguilla for use in aquaculture, so species identification methods are needed to monitor these activities and to facilitate conservation efforts. A method was developed to genetically distinguish two subspecies of the Indonesian short-finned eel, Anguilla bicolor, based on an allelic discrimination technique.

Results: A single DNA nucleotide substitution in the mitochondrial DNA 16S rRNA gene was employed to identify the two subspecies where Anguilla bicolor bicolor and Anguilla bicolor pacifica possessed adenine and guanine, respectively. This substitution was highly conserved at $100 \%$ in A. bicolor bicolor (108/108) and $99.9 \%$ in A. bicolor pacifica (181/182), and the misidentification rate was estimated to be $0.34 \%$. Subsequently, fluorescent-labeled oligo probes and PCR primers were designed and succeeded to clearly distinguish the two subspecies. Further, the other ten anguillid species that may be sympatrically distributed with A. bicolor showed negative results.
\end{abstract}

Conclusions: The method developed in this study is useful to accurately identify the two subspecies of A. bicolor and can contribute to ecological studies, stock management, and conservation.

Keywords: Allelic discrimination; Anguilla bicolor; Indonesian short-finned eel; Genetic identification; Red list

\section{Background}

Freshwater eels of the genus Anguilla have catadromous life histories in which they spawn in the open ocean and grow in freshwater or estuaries (Aoyama 2009). Anguillid glass eels have been harvested when they recruit to estuaries for use in aquaculture because artificial production of anguillids has not yet been established at a commercial scale. The populations of temperate species such as the European eel Anguilla anguilla and the Japanese eel Anguilla japonica, however, have decreased drastically in recent decades and are now classified as being Critically Endangered (A2bd + 4bd ver 3.1) and Endangered (A2bc ver 3.1) species by the International Union for Conservation of Nature (IUCN) since 2010 and 2014, respectively (Jacoby and Gollock 2014a, b). As an alternative to these endangered temperate species, tropical anguillids such as

\footnotetext{
* Correspondence: yosinaga@kitasato-u.ac.jp

${ }^{1}$ School of Marine Biosciences, Kitasato University, Kanagawa 252-0373, Japan Full list of author information is available at the end of the article
}

Anguilla bicolor, Anguilla luzonensis, and Anguilla marmorata have been introduced into aquaculture in recent years (TY, unpublished data). Especially for sale in Japan, A. bicolor has been harvested, raised, and processed in Indonesia and has already been mass-marketed in supermarkets. The latest version of the IUCN Red List, however, evaluated the stock status of $A$. bicolor being under threat by such rapidly increasing utilization, and the category of the species has been changed to the Near Threatened after previously being categorized as being the Least Concern in 2010 (Jacoby and Gollock 2014c).

A. bicolor is further divided taxonomically into the two subspecies of Anguilla bicolor bicolor in the Indian Ocean and Anguilla bicolor pacifica in the western North Pacific and northern Indonesian Seas (Ege 1939; Watanabe 2003). These two subspecies, however, are almost identical in their morphological characteristics except for the mode of their number of vertebrate (Watanabe et al. 2014), and only genetic characteristics enable them to be clearly 
divided into different subspecies. Currently, the most reliable information for distinguishing the two subspecies of A. bicolor is DNA nucleotide substitutions in a hypervariable region of the d-loop in their mitochondrial DNA (Minegishi et al. 2012).

Despite being genetically different, the latest assessment by the IUCN (ver 2014.1) considered the subspecies of some anguillids including A. bicolor together, due to a lack of basic ecological information for each subspecies (Jacoby and Gollock 2014c). Filling in such major gaps in the information such as species range and stock status available about tropical anguillids is critical to establish an effective management plan for these commercially utilized freshwater eels. However, one of the major obstacles for the ecological study in the tropical anguillid species is that the species identification with morphological characteristics is impossible (Ege 1939; Watanabe 2003). Accordingly, in this study, we developed a method to genetically distinguish the two subspecies of $A$. bicolor using a subspecies-specific DNA nucleotide substitution detected by an allelic discrimination analysis based on polymerase chain reaction (PCR). Because the glass eels of other anguillid species have been collected as bycatch with $A$. bicolor in tropical regions and introduced to aquaculture as unidentified mixed anguillid species in Japan (TY, unpublished data), the ability of the method to distinguish the two subspecies of $A$. bicolor from the other sympatrically distributed species in the Indian Ocean and the western North Pacific was also examined. The method developed in this study achieves a high-throughput analysis in a few hours and thus can be applied for both scientific and commercial purposes.

\section{Methods}

\section{Specimens}

Glass eels of $A$. bicolor were collected at two localities where only one of the two subspecies was known to recruit (Ege 1939; Watanabe 2003; Minegishi et al. 2012). The A. bicolor bicolor specimens were collected at the coast of the Sukabumi, West Java, Indonesia in September 2013 and imported to Japan for aquaculture ( $n=$ 108). The A. bicolor pacifica specimens were collected at the river mouth of the Cagayan River, northern Luzon, Philippines in November and December $2011(n=182)$ (Aoyama et al. 2014). Species identification of the specimens was carried out by determining partial DNA nucleotide sequences of the d-loop in the mitochondrial DNA for randomly selected sub-samples (A. bicolor bicolor, $n=23$ from Indonesia; A. bicolor pacifica, $n=28$ from Philippines). PCR primers of L15774 (5' -ACA TGA ATT GGA GGA ATA CCA GT-3'; Shields and Kocher 1991) and H16498aj (5'-CCT GAA ATA GGA ACC AAA TG-3'; modified from the original H16498 in
Kocher et al. 1989) were used as described in detail elsewhere (Yoshinaga et al. 2011, 2014).

\section{Designing PCR primers and probe for allelic discrimination}

To design PCR primers and a probe for the allelic discrimination of the two subspecies of A. bicolor, the DNA nucleotide sequences of the $16 \mathrm{~S}$ rRNA gene of the presently known 19 species/subspecies of the genus Anguilla were compared (Figure 1). The 16S rRNA gene was employed because the rate of intra- and interspecies substitutions was found to be adequate from the previous studies to establish a reliable method (Yoshinaga et al. 2011, 2014; Aoyama et al. 2014). A single DNA nucleotide substitution at the 1,318th position in the full-length $16 \mathrm{~S}$ rRNA gene $(1,704 \mathrm{bp} ;$ A. bicolor bicolor, AP007236; A. bicolor pacifica, AP007237) was employed as the subspecies-specific nucleotide variation where $A$. bicolor bicolor and A. bicolor pacifica possessed adenine (A) and guanine (G), respectively (Figure 1). Subsequently, forward and reverse primers were designed to amplify the region including the subspecies specific site: AD-Abic-16S-F1278v2, 5'-AAC CCC CAC GAG GAA CC-3'; AD-Abic-16S-R1420, 5'-GGG AAA GGA TTG CGC TGT TA-3' (Figure 1). The 3 '-end nucleotide of the forward primer was variable between the two subspecies of $A$. bicolor with cytosine (C) and the other 17 species/subspecies with thymine $(\mathrm{T})$ or gap. TaqMan minor groove binder (MGB; Applied Biosystems, Foster City, CA, USA) oligo probes were designed to specifically distinguish the specific substitution in the two subspecies: AD-BBI-16S-p, 5'-VIC-AAG CCA AGA AAT ACA CCT CT-NFQ-MGB-3' for A. bicolor bicolor; ADBPA-16S-p, 5'-FAM-AAG CCA AGA GAT ACA CCT CT-NFQ-MGB-3' for A. bicolor pacifica (Figure 1). The 5 '-end of these probes was modified with fluorescent reporter dyes of VIC and FAM, respectively, and the 3 '-end with non-fluorescent quencher (NFQ), to observe the amplification by a real-time monitoring thermal cycler.

\section{Intra- and inter-subspecies nucleotide variation}

To determine the intra- and inter-subspecies DNA nucleotide variation in the region for the allelic discrimination, partial DNA nucleotide sequences of the $16 \mathrm{~S}$ rRNA gene were analyzed for A. bicolor bicolor $(n=108)$ and A. bicolor pacifica $(n=182)$ with universal PCR primers of $16 \mathrm{~S}$-ar and $16 \mathrm{~S}$-br $\left(5^{\prime}\right.$-CGC CTG TTT ATC AAA AAC AT-3' and 5'-CTC CGG TTT GAA CTC AGA TCA-3', respectively; Palumbi et al. 1991). The specimens with a unique haplotype were further analyzed by determining the DNA nucleotide sequence of the d-loop region to confirm the subspecies identification. 


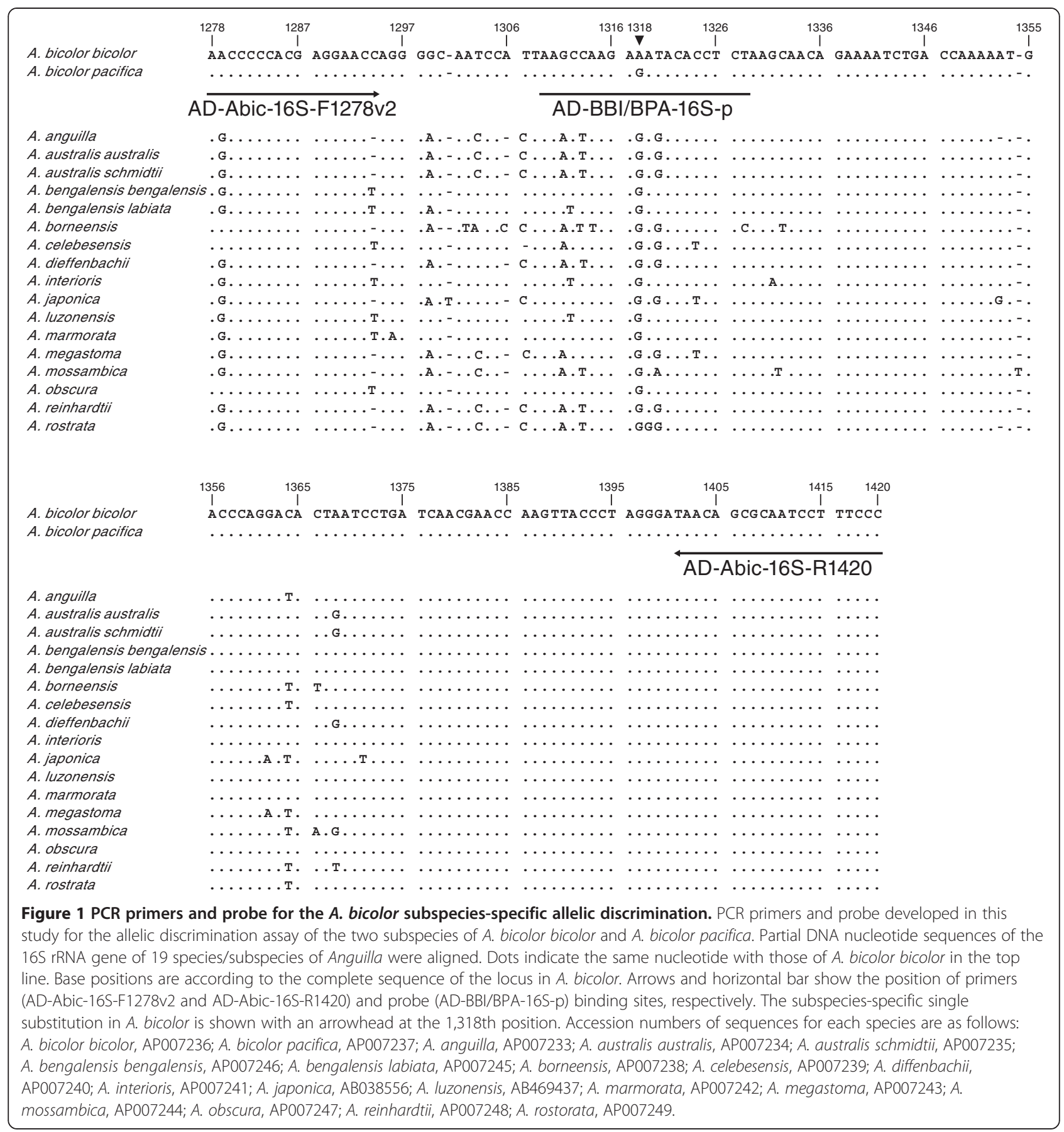

\section{Sensitivity and specificity of the allelic discrimination}

To verify the capabilities of the method developed in this study, four kinds of tests were performed: (1) To determine the sensitivity of the method, a serial dilution between $10 \mathrm{ng} / \mu \mathrm{L}$ and $10 \mathrm{fg} / \mu \mathrm{L}$, resulting in a range between $50 \mathrm{ng}$ and $50 \mathrm{fg}$ in each reaction, of the total genomic DNA was used in the assay. The total genomic DNA was prepared using a DNeasy Blood \& Tissue Kit (Qiagen, Venlo, the Netherlands), and the DNA concentration was quantified using a Qubit Fluorometric Quantitiation system with a dsDNA HS Assay Kit (Life Technologies, Waltham, MA, USA). (2) Three and four haplotypes in A. bicolor bicolor and A. bicolor pacifica, respectively (see the 'Results' section), were tested at the DNA concentration of $1 \mathrm{ng} /$ $\mu \mathrm{L}$ each (5 ng in each reaction). (3) To achieve a highthroughput and cost-effective method, the template DNA was prepared by a HotSHOT method (Truett et al. 2000) with a slight modification. A small portion 
of tissue was boiled in $50 \mu \mathrm{L}$ of $50 \mathrm{mM}$ sodium hydroxide at $95^{\circ} \mathrm{C}$ for $20 \mathrm{~min}$, neutralized with $5 \mu \mathrm{L}$ of $1 \mathrm{M}$ Tris- $\mathrm{HCl}, \mathrm{pH} 8$, and then the supernatant was used for the allelic discrimination. (4) As the other anguillid species that are commercially harvested with $A$. bicolor, the Indian Ocean species of Anguilla bengalensis bengalensis, Anguilla bengalensis labiata, Anguilla mossambica, and the western North Pacific species of Anguilla celebesensis, Anguilla japonica, Anguilla luzonensis, and the common or possibly present species in the two oceans of Anguilla borneensis, Anguilla interioris, Anguilla marmorata, and Anguilla obscura were examined at the DNA concentration of $1 \mathrm{ng} / \mu \mathrm{L}$ each (5 $\mathrm{ng}$ in each reaction).

A total of $20 \mu \mathrm{L}$ of reaction contained $10 \mu \mathrm{L}$ of a TaqMan Universal PCR master mix (Applied Biosystems), $0.4 \mu \mathrm{M}$ each AD-Abic-16S-F1278v2 and AD-Abic-16SR1420 primers, 3.8 pmol each of the AD-BBI-16S-p and AD-BPA-16S-p probes, and $5 \mu \mathrm{L}$ of template DNA. The reaction was carried out with an ABI PRISM 7000/7300 Sequence Detection Systems (Applied Biosystems) with a thermal profile of an initial step at $50^{\circ} \mathrm{C}$ for $2 \mathrm{~min}$ and $95^{\circ} \mathrm{C}$ for $10 \mathrm{~min}$, and then 50 cycles of $95^{\circ} \mathrm{C}$ for $15 \mathrm{~s}, 60^{\circ} \mathrm{C}$ for $15 \mathrm{~s}$, and $72^{\circ} \mathrm{C}$ for $45 \mathrm{~s}$. The allelic discrimination analyses were performed according to the manufacturer's protocol (Applied Biosystems).

\section{Results}

\section{Haplotypes}

A total of three and four haplotypes were identified in $A$. bicolor bicolor (BBI-HT1-3; $n=108)$ and A. bicolor pacifica (BPA-HT1-4; $n=182$ ), respectively (Figure 2). In both of the two subspecies, the most frequent types (BBI-HT1, 97.2\%; BPA-HT1, 97.8\%) were the same with those used for the primer and probe design (Figure 1). In A. bicolor bicolor, one DNA nucleotide substitution was found in the probe binding region $(1,320$ th in BBIHT2, $0.9 \%$ ), and another one was between the probe and reverse primer binding sites (1,368th in BBI-HT3, 1.9\%) (Figure 2). The DNA nucleotide substitutions in A. bicolor pacifica were all in the probe binding region, and one haplotype was identical with the BBI-HT1 in A. bicolor bicolor (BPA-HT2, 0.5\%). The other two types were unique among the seven types found in this study $(1,320$ th in BPA-HT3, 1.1\%; 1,323rd in BPA-HT4, 0.5\%), respectively. Accordingly, it was found that a single DNA nucleotide substitution at 1,318th site of the $16 \mathrm{~S}$ rRNA gene was highly conserved in the two subspecies of $A$. bicolor, except for the BPA-HT2 in A. bicolor pacifica (Figure 2).

The DNA nucleotide sequences of the seven haplotypes were deposited in the DDBJ/EMBL/GenBank databases with accession numbers of AB971267 to AB971269

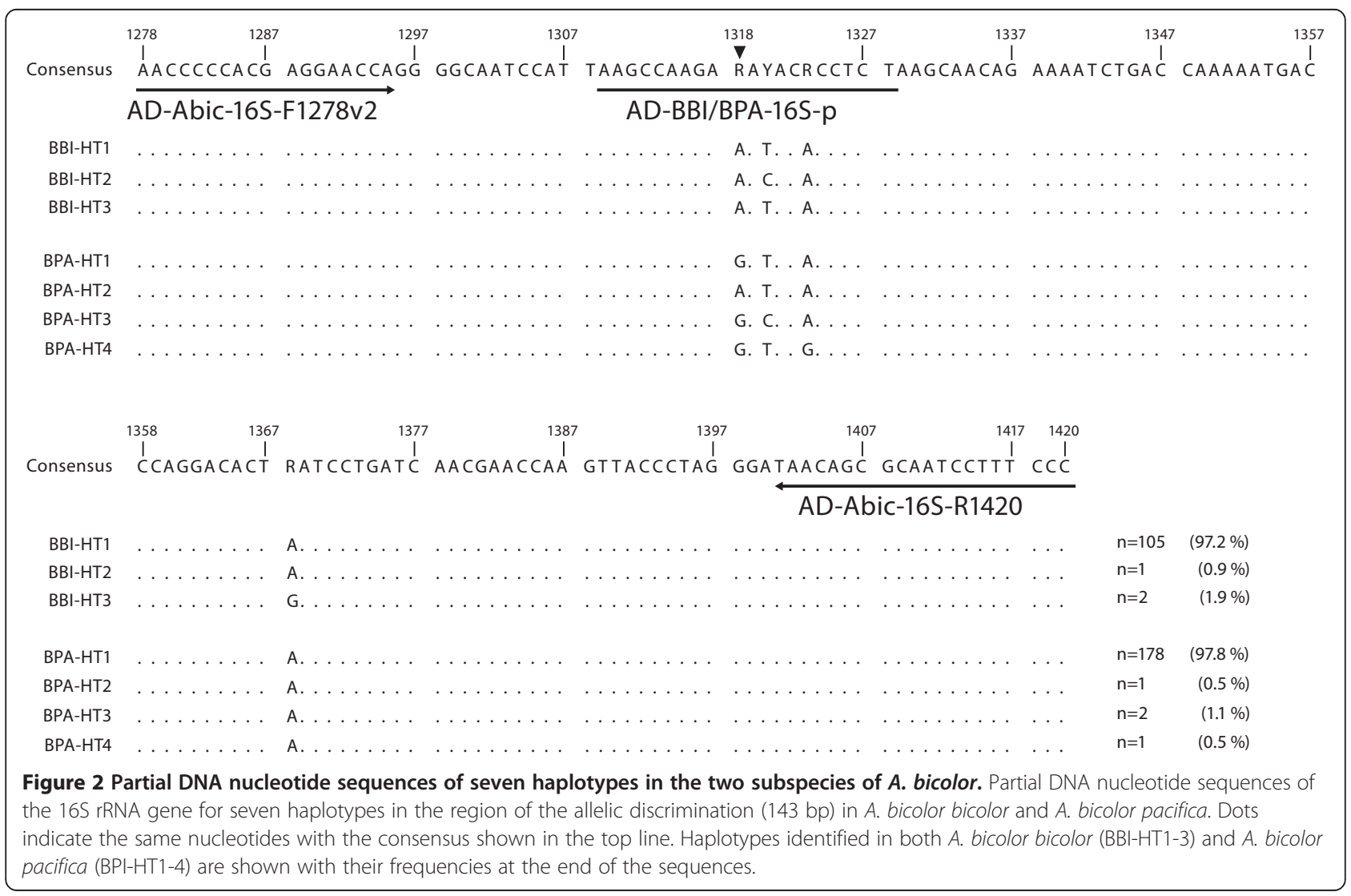


(BBI-HT1-3 in A. bicolor bicolor) and AB971270 to AB971273 (BPA-HT1-4 in A. bicolor pacifica).

\section{Allelic discrimination analyses}

Sensitivity of the allelic discrimination assay was examined in the range of $50 \mathrm{fg}$ to $50 \mathrm{ng}$ of genomic DNA in each reaction, and higher fluorescence intensities were observed in the reaction with a larger amount of the template DNA (Figure 3a). The two subspecies of $A$. bicolor were found to be clearly discriminated when the total genomic DNA amount of larger than $50 \mathrm{pg}$ was used in the reaction (symbols a-d in Figure 3a).

In the second test, among the total seven haplotypes in A. bicolor, one haplotype of BPA-HT2 in A. bicolor pacifica was wrongly discriminated as A. bicolor bicolor as was predicted from its nucleotide substitution at the 1,318th position (Figure 2), while the other six haplotypes were precisely identified as each subspecies (Figure 3b).

When the total genomic DNA prepared by the HotSHOT method was applied in the reaction, no amplification was observed. In contrast, 1/10 dilution of the supernatant with water significantly improved the amplification and resulted in the successful discrimination (data not shown). The DNA concentrations for the 1/10 diluted supernatant, determined by the Qubit system, were $234.7 \pm 106.5 \mathrm{pg} / \mu \mathrm{L}$ (average \pm s.d.; range, 56.8 to $354.0 ; n=10)$ and were found to be in the range determined by the sensitivity test (Figure 3a).

The other ten anguillid species were tested with the primers and probe designed for A. bicolor, and all were discriminated as being negative (Figure 3c).

\section{Discussion}

DNA nucleotide sequencing provides the most reliable results for species identification in the genus Anguilla, but it requires a high cost in time and labor and stable environment for sophisticated laboratory equipments (Yoshinaga et al. 2014; Aoyama et al. 2014). To compensate for these disadvantages, alternative methods such as the species-specific PCR have been developed. Watanabe et al. (2004) and Minegishi et al. (2009) developed a method to identify egg or larval specimens of the Japanese eel $A$. japonica onboard during oceanic sampling surveys of the spawning area by using an A. japonica-specific fluorescent-labeled probe, and this contributed to the discovery of naturally spawned eggs of this species for the first time (Tsukamoto et al. 2011; Yoshinaga et al. 2011). Itoi et al. (2005) also reported a method to distinguish the commercially distributed species of A. japonica and $A$. anguilla using specific probes for each species. In addition, to identify seven species/subspecies of Anguilla in Indonesian waters, Fahmi et al. (2013) used PCR primers specific to each species/subspecies. Batch analysis based on the species-specific PCR primer to verify the presence of $A$. japonica has also been recently reported (Suzuki et al. 2011).

In this study, we developed a method to distinguish the two subspecies of $A$. bicolor whose morphological characteristics are not sufficient to identify them accurately. To determine the subspecies-specific DNA nucleotide substitution, we compared the sequences of the partial fragments of the mitochondrial 16S rRNA gene and detected a transition substitution of adenine and guanine, which were specific to A. bicolor bicolor and $A$. bicolor pacifica, respectively (Figure 1 ), except for the rare haplotype found in A. bicolor pacifica (Figure 2). Subsequently, we designed fluorescent-labeled oligo probes to detect the subspecies-specific single DNA nucleotide substitution by the allelic discrimination method. In PCRbased identification methods, the DNA nucleotide substitutions in a single species (intra-species variation) should be carefully taken into account, especially to distinguish genetically closed groups such as subspecies. However, it is hard to comprehensively catalog the haplotypes in each species due to a sampling difficulty especially in the tropical anguillid species whose species ranges are not yet known. On the other hand, A. bicolor bicolor and A. bicolor pacifica distribute widely in the Indian Ocean and the western North Pacific, but each subspecies shares common gene pool even for the A. bicolor bicolor present at the western and eastern sides of the Indian Ocean (Minegishi et al. 2012). This allowed us to assume that the specimens of the two subspecies collected at a single locality in the Indian Ocean (Indonesia) and the western North Pacific (Philippines) represented the genetic characteristics of each subspecies. We examined intra-subspecies variation with a large number of specimens of both A. bicolor bicolor and $A$. bicolor pacifica and identified three and four haplotypes, respectively (Figure 2). Frequencies of each haplotype were strongly skewed, and the commonest type was present in more than $97 \%$ of the individuals in each subspecies. One haplotype in A. bicolor pacifica (BPA-HT2), however, possessed the substitution of the A. bicolor bicolor type and resulted in the misidentification by the allelic discrimination (Figure 3b). On the other hand, the other haplotypes were clearly discriminated even though the substitution existed in the probe binding region (Figure 2). Accordingly, among the 290 specimens of A. bicolor examined in this study, only 1 specimen had a substitution causing misidentification, and thus, an error rate was estimated to be $0.34 \%(1 / 290)$.

In the allelic discrimination assay with the HotSHOT method, 1/10 dilution of the supernatant yielded stable results, probably due to an unidentified inhibiting factor(s) in the original solution since the method did not guarantee the uncontaminated DNA fraction, but is still suitable for the PCR (Truett et al. 2000). The HotSHOT method does not require a digestion enzyme or purification 
Figure 3 Allelic discrimination assays for the two subspecies of A. bicolor. The two fluorescent reporter dyes of VIC and FAM were used for subspecies-specific probes of A. bicolor bicolor and A. bicolor pacifica, respectively (Figure 1), and fluorescence intensities of each dye are plotted. The no template control (NTC) is shown with a cross symbol. (a) Various amounts of template DNA were tested for both A. bicolor bicolor (open circles) and A. bicolor pacifica (closed circles): a, $50 \mathrm{ng} ; b, 5 \mathrm{ng} ; c, 500 \mathrm{pg} ; d, 50$ pg; e, 5 pg; f, 500 fg; g, 50 fg in each reaction. (b) Three and four haplotypes in A. bicolor bicolor (open circles; BBI-HT1-3) and A. bicolor pacifica (closed circles; BPA-HT1-4), respectively, were tested (Figure 2). (c) The ten anguillid species were tested with the two subspecies of $A$. bicolor, and the first three characters of each species name are shown instead of symbols. beb, $A$. bengalensis bengalensis; bel, $A$. bengalensis labiata; mos, A. mossambica; cel, A. celebesensis; jap, A. japonica; luz, A. luzonensis, bor, A. borneensis; int, A. interioris; mar, A. marmorata; obs, A. obscura.

column and is appropriate for a low-cost and highthroughput allelic discrimination assay.

We also tested the ability of the method to distinguish the two subspecies of $A$. bicolor from the other anguillid species. Ten species, which have been known to sympatrically recruit with A. bicolor (Ege 1939; Watanabe 2003; Yoshinaga et al. 2014), were examined, and all showed negative results (Figure 3c). This might be due to mismatch at the 3 '-end of the forward primer (Figure 1), and PCR amplification did not occur, or did with significantly lesser efficiency, in the other species. However, careful attention should be paid to apply the method to the other species, because haplotypes have been almost solely studied in temperate species such as the Japanese eel A. japonica and the European eel $A$. anguilla, and information on tropical species is scarce. Future investigation of haplotype diversity is essential to evaluate the usefulness of the method to be used for the other anguillid species of A. bicolor.

\section{Conclusions}

The Indonesian archipelago has been known to have the highest species richness of anguillid eels, and 7 (Aoyama et al. 2001) or 9 (Sugeha et al. 2008) among the total of 19 species/subspecies have been reported to occur. These include the two subspecies of $A$. bicolor, but the boundary or overlapping parts of the ranges of the two subspecies have not yet been established. Areas that have currents from both the Indian Ocean and North Pacific, such as Malaysia and Thailand, may have some recruitment of either or both of the two A. bicolor subspecies. There has been some progress in the ecological study of $A$. bicolor bicolor (Chino and Arai 2010a, b; Arai et al. 2012, 2013; Arai and Chino 2013), and this should be expanded to cover the wider distribution range of this species in the Indian Ocean and the western North Pacific to accumulate information for assessing its population status. The method developed in this study can be helpful to clarify the distribution ranges of the two subspecies of $A$. bicolor, 
and such basic ecological information should be considered to evaluate the status of these subspecies, because the increasing commercial fishing activity may quickly cause their populations to decline as have the temperate anguillid species.

\section{Competing interests}

The authors declare that they have no competing interests.

\section{Authors' contributions}

TY designed the experiments and wrote the manuscript. CT, FS, MS, MI, and TY carried out the experiments. JA and AS participated in the sample collection. All authors read and approved the final manuscript.

\section{Acknowledgements}

This study was financially supported by a grant from the Fisheries Agency of Japan to TY and AS, and a Grant-in-Aid for Scientific Research (C) from the Japan Society for the Promotion of Science (No. 40111489) to AS, AJ, and TY. The authors would like to thank MJ Miller and two anonymous reviewers for helping to improve the manuscript.

\section{Author details}

${ }^{1}$ School of Marine Biosciences, Kitasato University, Kanagawa 252-0373, Japan. ${ }^{2}$ Department of Biology, Tokyo Medical University, Tokyo 160-8402, Japan. ${ }^{3}$ Atmosphere and Ocean Research Institute, The University of Tokyo, Chiba 277-8564, Japan.

Received: 7 July 2014 Accepted: 21 August 2014

Published online: 14 September 2014

\section{References}

Aoyama J (2009) Life history and evolution of migration in catadromous eels (genus Anguilla). Aqua-BioScience Monographs 2:1-42

Aoyama J, Nishida M, Tsukamoto K (2001) Molecular phylogeny and evolution of the freshwater eel, genus Anguilla. Mol Phylogen Evol 20:450-459

Aoyama J, Yoshinaga T, Shinoda A, Shirotori F, Yambot AV, Han Y-S (2014) Seasonal changes in species composition of glass eels of the genus Anguilla (Teleostei: Anguillidae) recruiting to the Cagayan River. Pacific Sci, Luzon Island, the Philippines, in press

Arai T, Chino N (2013) Timing of maturation of a tropical eel, Anguilla bicolor bicolor in Malaysia. J Appl Ichthyol 29:271-273

Arai T, Chino N, Zulkifli SZ, Ismail A (2012) Notes on the occurrence of the tropical eel Anguilla bicolor bicolor in Peninsular Malaysia, Malaysia. J Fish Biol 80:692-697

Arai T, Chino N, Le DQ (2013) Migration and habitat use of the tropical eels Anguilla marmorata and A. bicolor pacifica in Vietnam. Aquat Ecol 47:57-65

Chino N, Arai T (2010a) Habitat use and habitat transitions in the tropical eel, Anguilla bicolor bicolor. Env Biol Fishes 89:571-578

Chino N, Arai T (2010b) Occurrence of marine resident tropical eel Anguilla bicolor bicolor in Indonesia. Mar Biol 157:1075-1081

Ege V (1939) A revision of the genus Anguilla Shaw, a systematic, phylogenetic and geographical study. Dana Rep 16:1-256

Fahmi MR, Solihin DD, Soewardi K, Pouyaud L, Shao Z, Berrebi P (2013) A novel semi-multiplex PCR assay for identification of tropical eels of genus Anguilla in Indonesian waters. Fish Sci 79:185-191

Itoi S, Nakaya M, Kaneko G, Kondo H, Sezaki K, Watabe S (2005) Rapid identification of eels Anguilla japonica and Anguilla anguilla by polymerase chain reaction with single nucleotide polymorphism-based specific probes. Fish Sci 71:1356-1364

Jacoby D, Gollock M (2014a) Anguilla anguilla. In: IUCN Red List of Threatened Species, Ver, p 1, http://www.iucnredlist.org/details/60344/0. Accessed 26 Aug 2014

Jacoby D, Gollock M (2014b) Anguilla japonica. In: IUCN Red List of Threatened Species, Ver, p 1, http://www.iucnredlist.org/details/166184/0. Accessed 26 Aug 2014

Jacoby D, Gollock M (2014c) Anguilla bicolor. In: IUCN Red List of Threatened Species, Ver, p 1, http://www.iucnredlist.org/details/166894/0. Accessed 26 Aug 2014

Kocher TD, Thomas WK, Meyer A, Edwards SV, Pääbo S, Villablanca FX, Wilson AC (1989) Dynamics of mitochondrial DNA evolution in animals: amplification and sequencing with conserved primers. Proc Natl Acad Sci U S A 86:6196-6200

Minegishi Y, Yoshinaga T, Aoyama J, Tsukamoto K (2009) Species identification of Anguilla japonica by real-time PCR based on a sequence detection system: a practical application to eggs and larvae. ICES J Mar Sci 66:1915-1918

Minegishi Y, Gagnaire P-A, Aoyama J, Bosc P, Feunteun E, Tsukamoto K, Berrebi P (2012) Present and past genetic connectivity of the Indo-Pacific tropical eel Anguilla bicolor. J Biogeography 39:408-420

Palumbi SR, Martin AP, Romano SL, McMillan WO, Stice L, Grabowski G (1991) The simple fool's guide to PCR. University of Hawaii, Honolulu, Department of Zoology

Shields GF, Kocher TD (1991) Phylogenetic relationships of North American ursids based on analysis of mitochondrial DNA. Evolution 45:218-221

Sugeha HY, Suharti SR, Wouthuyzen S, Sumadhiharga K (2008) Biodiversity, distribution and abundance of the tropical anguillid eels in the Indonesian waters. Mar Res Indonesia 33:129-137

Suzuki H, Kimoto M, Yoshizoe Y, Tsuneyoshi T, Asai N, Ueda M, Kubota H, Kubota $T$ (2011) DNA analysis method for detecting the mixing of foreign species of eel among many Anguilla japonica eels. Nippon Suisan Gakkaishi 77:896-901 (in Japanese)

Truett GE, Heeger P, Mynatt RL, Truett AA, Walker JA, Warman ML (2000) Preparation of PCR-quality mouse genomic DNA with hot sodium hydroxide and tris (HotSHOT). Biotechniques 29:52-54

Tsukamoto K, Chow S, Otake T, Kurogi H, Mochioka N, Miller MJ, Aoyama J, Kimura S, Watanabe S, Yoshinaga T, Shinoda A, Kuroki M, Oya M, Watanabe T, Hata K, ljiri S, Kazeto Y, Nomura K, Tanaka H (2011) Oceanic spawning ecology of freshwater eels in the western North Pacific. Nat Commun 2:179

Watanabe S (2003) Taxonomy of the freshwater eels, genus Anguilla Schrank, 1798. In: Aida K, Tsukamoto K, Yamauchi K (eds) Eel biology. Springer, Tokyo, pp 3-18

Watanabe S, Minegishi Y, Yoshinaga T, Aoyama J, Tsukamoto K (2004) A quick method for species identification of the Japanese eel (Anguilla japonica) using real-time PCR: an onboard application for use during sampling surveys. Mar Biotechnol 6:566-574

Watanabe S, Miller MJ, Aoyama J, Tsukamoto K (2014) Evaluation of the population structure of Anguilla bicolor and A. bengalensis using total number of vertebrae and consideration of the subspecies concept for the genus Anguilla. Ecol Freshwat Fish 23:77-85

Yoshinaga T, Miller MJ, Yokouchi K, Otake T, Kimura S, Aoyama J, Watanabe S, Shinoda A, Oya M, Miyazaki S, Zenimoto K, Sudo R, Takahashi T, Ahn H, Manabe R, Hagihara S, Morioka H, Itakura H, Machida M, Ban K, Shiozaki M, Ai B, Tsukamoto K (2011) Genetic identification and morphology of naturally spawned eggs of the Japanese eel Anguilla japonica collected in the western North Pacific. Fish Sci 77:983-992

Yoshinaga T, Aoyama J, Shinoda A, Watanabe S, Azanza RV, Tsukamoto K (2014) Occurrence and biological characteristics of glass eels of the Japanese eel Anguilla japonica at the Cagayan River of Luzon Island, Philippines in 2009. Zool Stud 53:13

\section{doi:10.1186/s40555-014-0057-8}

Cite this article as: Tanaka et al:: Genetic identification method for two subspecies of the Indonesian short-finned eel, Anguilla bicolor, using an allelic discrimination technique. Zoological Studies 2014 53:57.

\section{Submit your manuscript to a SpringerOpen ${ }^{\odot}$ journal and benefit from:}

- Convenient online submission

Rigorous peer review

- Immediate publication on acceptance

- Open access: articles freely available online

- High visibility within the field

- Retaining the copyright to your article

Submit your next manuscript at $\gg$ springeropen.com 